\title{
Autonomic support of endurance, strength and speed performance in athletes
}

\author{
S. M. Kanyhina ${ }^{\mathbb{D} * \text { B,F, }}$, V. V. Syvolap $\mathbb{D}^{\mathrm{C}, \mathrm{D}}$, M. S. Potapenko ${ }^{\mathrm{A}, \mathrm{E}}$ \\ Zaporizhzhia State Medical University, Ukraine
}

A - research concept and design; B - collection and/or assembly of data; C - data analysis and interpretation; D - writing the article;

$\mathrm{E}$ - critical revision of the article; $\mathrm{F}$ - final approval of the article

Examining the autonomic support of muscular activity in athletes enables an assessment of the ANS impact on achieving a high-level of sports performance at different ages, an identification of interaction patterns between the ANS divisions in the process of short-term and long-term adaptation to muscular load, identifying the features of the cardiovascular system autonomic regulation in athletes training different physical performance

Aim. To examine heart rate variability (HRV) changes in athletes depending on the training session mode.

Material and methods. A total of 104 athletes (84 men and 20 women) were enrolled in the study: 63 - endurance-trained athletes, 31 - strength-trained and 10 - speed-trained athletes. The mean age of the athletes was $21.75 \pm 3.32$ years. Among them, there were Masters of Sports of International Class (MSIC) -2 athletes, Masters of Sports (MS) - 25, Candidates Master of Sports (CMS) -48, First-Class athletes -29. All the athletes underwent HRV analysis on the device "Cardio+" (NPP "Metekol", Nizhyn, Ukraine).

Results. HRV in the endurance and strength athletes indicated a predominance of heart rate (HR) by $11.4 \%(61.03 \pm 10.19$ vs. $68.00 \pm 7.72 \mathrm{bpm}, \mathrm{P}=0.004)$, Mode $(\mathrm{Mo})$ value $(954(860 ; 1103)$ vs. $868(798 ; 954) \mathrm{ms})$ by $9.0 \%(\mathrm{P}=0.004)$ and shorter mean RR interval duration (Mean) by $11.7 \%$ (1002.45 $\pm 168.59 \mathrm{vs} .885 .22 \pm 98.98 \mathrm{~ms}, \mathrm{P}=0.002)$ in comparison with the strength athletes. The endurance athletes had significantly lower values of SDNN by $7.6 \%(P=0.048)$, RMSSD by $35.5 \%$ $(P=0.029)$, SDANN by $26.4 \%$, and the predominance of Mo by $4.1 \%(P=0.016)$ in contrast to the speed athletes. There was no statistically significant difference between other HRV parameters between the endurance and speed athletes. Comparison of HRV between the strength and speed athletes revealed that the strength athletes had significantly $8.8 \%(P=0.042)$ higher $\mathrm{HR}(68.00 \pm 7.72$ vs. $62.00 \pm 7.14 \mathrm{bpm})$. Compared with the speed athletes, the strength athletes had significantly shorter RR interval duration $(885.22 \pm 98.98 \mathrm{vs} .969 .56 \pm 112.28 \mathrm{~ms})$ by $9.5 \%(P=0.046)$, higher values of SDNN by $9.5 \%(P=0.017)$, RMSSD by $68.9 \%(P=0.012)$, SDANN by $71.8 \%(P=0.015), C V r$, \% by $15.0 \%(P=0.045)$, Mo by $5.4 \%(P=0.029)$ that was indicative of sympathetic hyperactivity in the strength athletes.

Conclusions. The endurance and speed athletes did not differ from each other in all the spectral and the vast majority of time-domain HRV parameters, except for SDNN, RMSSD, SDANN and Mo. The strength athletes differed from the endurance athletes by higher tone of the sympathetic arm of the ANS, as evidenced by significantly $11.4 \%$ higher heart rate, $11.7 \%$ shorter RR interval duration and $9.0 \%$ lower Mo value. The speed and endurance athletes differed from the strength athletes by higher parasympathetic tone as evidenced by significantly $8.8 \%(P=0.042)$ lower heart rate, $9.5 \%(P=0.046)$, higher RR interval duration, values of SDNN by $9.5 \%(P=0.017)$, RMSSD by $68.9 \%(P=0.012)$, SDANN by $71.8 \%$ $(P=0.015), C V r, \%$ by $15.0 \%(P=0.045)$, Mo by $5.4 \%(P=0.029)$.

\section{Вегетативне забезпечення фізичних якостей витривалості, сили, швидкості у спортсменів}

\section{С. М. Канигіна, В. В. Сиволап, М. С. Потапенко}

Вивчення вегетативного забезпечення м'язової діяльності у спортсменів дає можливість оцінити внесок вегетативної нервової системи в досягнення високих спортивних результатів у різні вікові періоди, виявити закономірності взаємодії відділів вегетативної нервової системи у процесі короткотривалої та довготривалої адаптації до м'язових навантажень, встановити особливості вегетативної регуляції серцево-судинної системи у спортсменів, які тренують різні фізичні якості.

Мета роботи - дослідити зміни варіабельності серцевого ритму (ВСР) у спортсменів залежно від спрямованості тренувального процесу.

Матеріали та методи. У дослідженні взяли участь 104 спортсмени (84 чоловіки та 20 жінок): 63 - атлети, які розвивали переважно якість витривалості, 31 - якість сили, 10 - якість швидкості. Середній вік обстежених - 21,75 \pm 3,32 року. Серед них майстрів спорту міжнародного класу (МСМК) - 2 спортсмени, майстрів спорту (MC) -25 , кандидатів у майстри спорту - 48, спортсменів 1 розряду - 29. Усім спортсменам виконали аналіз ВСР на апараті «Кардіо+» (НПП «Метекол», м. Ніжин, Україна).

Результати. Порівняння показників варіабельності серцевого ритму у спортсменів, які розвивали якість витривалості або сили, свідчить про переважання частоти серцевих скорочень (ЧСС) на 11,4 \% (61,03 \pm 10,19 уд/хв проти 68,00 $\pm 7,72$ уд/хв, $p=0,004)$, показника моди $(954(860 ; 1103)$ мс проти 868 (798; 954) мс) на 9,0\% (P = 0,004) та меншу середню тривалість інтервалу R-R (Mean) на 11,7 \% (1002,45 \pm 168,59 мс проти 885,22 \pm 98,98 мс, p = 0,002) у спортсменів, які розвивали якість сили. У спортсменів, які розвивали якість витривалості, визначили вірогідно менші значення показників SDNN на 7,6 \% ( $p=0,048)$, RMSSD на $35,5 \%$ ( $p=0,029)$, SDSD на $26,4 \%$, переважання показника моди на $4,1 \%$,
Key words: athletes, endurance, strength, speed, heart rate variability.

Zaporozhye medical journal 2020; $22(6), 767-774$

*E-mail: malakhova sn@ukr.net

Киючові слова: спортсмени, витривалість, сила, швиАкість, варіабельність ритму серця.

Запорізький медичний журнал 2020. T. 22, № 6(123). C. 767-774 
( $p=0,016)$, на відміну від спортсменів, які розвивали якість швидкості. Статистично вірогідної різниці інших показників ВРС у спортсменів, які розвивали якості витривалості або швидкості, не встановили. Порівняння показників ВРС у спортсменів, які розвивали якості сили або швидкості, доводить: у силових атлетів вірогідно більша на 8,8 \% (p=0,042) ЧСС (68,00 $\pm 7,72$ уд/хв проти $62,00 \pm 7,14$ уд/хв). Порівнюючи зі спортсменами, які розвивали якість швидкості, атлети, які розвивали якість сили, мали вірогідно меншу тривалість інтервалу R-R (Mean) $(885,22 \pm 98,98$ мс проти 969,56 $\pm 112,28$ мc) на 9,5\% ( $p=0,046)$, величину показника SDNN на 9,5\% ( $p=0,017)$, RMSSD на 68,9 \% ( $p=0,012)$, SDSD на $71,8 \%$ ( $p=0,015), C V r, \%$ на 15,0 \% ( $p=0,045)$, моди на 5,4 \% ( $=0,029)$; це свідчить про переважання в силових атлетів активності симпатичної ланки ВНС

Висновки. Спортсмени, які розвивали якості витривалості або швидкості, не відрізнялися за всіма спектральними та більшістю часових показників BCP, крім показників SDNN, RMSSD, SDSD і моди. Спортсмени, які розвивали якість сили, відрізнялися від спортсменів, які розвивали якість витривалості, більшим тонусом симпатичної ланки ВНС, про що свідчить вірогідно більша на 11,4% ЧСC, менша тривалість інтервалу R-R на 11,7 \% та менша величина показника моди на 9,0\%. Спортсмени, які розвивали якість швидкості, як і якість витривалості, відрізнялися від спортсменів, які розвивали якість сили, більшим тонусом парасимпатичної НС. Про це свідчить вірогідно менша чСС на 8,8 \% ( $p=0,042)$, більша тривалість інтервалу R-R на 9,5 \% ( $p=0,046)$, більші значення SDNN на 9,5\% ( $p=0,017)$, RMSSD на 68,9 \% ( $p=0,012)$, SDSD на 71,8 \% ( $p=0,015)$, CVr, \% на 15,0 \% ( $p=0,045)$, моди на 5,4 \% ( $p=0,029)$.

Ключевые слова: спортсмены, выносливость, сила, скорость, вариабельность ритма сердца.

Запорожский медицинский журнал 2020. T. 22, № 6(123).

C. $767-774$

\section{Вегетативное обеспечение физических качеств выносливости, силы, скорости у спортсменов}

\section{С. Н. Каныгина, В. В. Сыволап, М. С. Потапенко}

Изучение вегетативного обеспечения мышечной деятельности у спортсменов дает возможность оценить вклад вегетативной нервной системы в достижение высоких спортивных результатов в различные возрастные периоды, позволяет выявить закономерности взаимодействия отделов вегетативной нервной системы в процессе кратковременной и долговременной адаптации к мышечным нагрузкам, установить особенности вегетативной регуляции сердечно-сосудистой системы у спортсменов, тренирующих различные фризические качества.

Цель работы - изучить изменения вариабельности сердечного ритма (ВСР) у спортсменов в зависимости от направленности тренировочного процесса.

Материалы и методы. Обследовали 104 спортсменов (84 мужчины, 20 женщин): 63 - атлеты, которые развивали преимущественно качество выносливости, 31 - качество силы, 10 - качество скорости. Средний возраст обследованных $-21,75 \pm 3,32$ года. Среди них мастеров спорта международного класса (МСМК) -2 спортсмена, мастеров спорта (MC) -25 , кандидатов в мастера спорта - 48, спортсменов 1 разряда -29. Всем спортсменам выполнен анализ ВСР на аппарате «Кардио+» (НПП «Метекол», г. Нежин, Украина).

Результаты. Сравнение показателей вариабельности сердечного ритма у спортсменов, которые развивали качество выносливости или силы, свидетельствует о преобладании частоты сердечных сокращений (ЧСС) на 11,4 \% (61,03 \pm 10,19 уд/мин против $68,00 \pm 7,72$ уд/мин, $р=0,004)$, показателя моды (954 (860; 1103) мс против $868(798 ; 954)$ мс) на 9,0\% $(p=0,004)$ и меньшую среднюю продолжительность интервала RR (Mean) на 11,7 \% (1002,45 \pm 168,59 мс против $885,22 \pm 98,98$ мс, $p=0,002)$ у спортсменов, развивающих качество силы. У спортсменов, которые развивали качество выносливости, достоверно меньше значения показателей SDNN на 7,6 \% ( $p=0,048)$, RMSSD на 35,5 \% ( $p=0,029)$, SDSD на 26,4 \%, и преобладание показателя моды на 4,1 \% ( $=0,016)$, в отличие от спортсменов, развивающих качество скорости. Статистически достоверная разница других показателей ВСР у спортсменов, которые развивали качества выносливости или скорости, не установлена. Сравнение показателей ВСР у спортсменов, развивающих качества силы или скорости, доказывает: у атлетов-силовиков достоверно больше на 8,8 \% ( $p=0,042)$ ЧСС $(68,00 \pm 7,72$ уд/мин против $62,00 \pm 7,14$ уд/мин). По сравнению со спортсменами, которые развивали качество скорости, атлеты, развивающие качество силы, имели достоверно меньшую продолжительность интервала RR (Mean) $(885,22 \pm 98,98$ мс против 969,56 $\pm 112,28$ мс) на 9,5 \% ( $p=0,046)$, величину показателя SDNN на 9,5\% ( $p=0,017)$, RMSSD на $68,9 \%$ $(p=0,012), \operatorname{SDSD}$ на $71,8 \%(p=0,015), \mathrm{CVr}, \%$ на $15,0 \%(p=0,045)$, моды на $5,4 \%(p=0,029)$, что свидетельствует о преобладании у атлетов-силовиков активности симпатического звена ВНС.

Выводы. Спортсмены, которые развивали качества выносливости или скорости, не отличались по всем спектральным и большинству временных показателей BCP, за исключением показателей SDNN, RMSSD, SDSD и моды. Спортсмены, развивающие качество силы, отличались от спортсменов, развивающих качество выносливости, большим тонусом симпатического звена ВНС, о чем свидетельствует достоверно большая на $11,4 \%$ ЧСС, меньшая продолжительность интервала RR на 11,7 \% и меньшая величина показателя моды на 9,0%. Спортсмены, развивающие качество скорости, как и качество выносливости, отличались от спортсменов, развивающих качество силы, большим тонусом парасимпатической НС, о чем свидетельствует достоверно меньшая ЧСС на 8,8 \% ( $p=0,042)$, большая продолжительность интервала RR на 9,5 \% ( $p=0,046)$, большие значения SDNN на 9,5 \% ( $p=0,017)$, RMSSD на 68,9 \% ( $p=0,012)$, SDSD на 71,8\% ( $p=0,015), C V r, \% 150 \%$ ( $p=0,045)$, моды на $5,4 \%(p=0,029)$.

Heart rate variability (HRV) is an integral indicator of the cardiovascular system and human body functional state as it is related to a present functional state and adaptive reserves of an athlete's body assessment, identification of a maladaptation and overtraining at the early stages, as well as it helps to design a more rational program of training sessions [13]. HRV in athletes depends on an experience and class [3], anthropometric characteristics [5,10], age and sex [6,9], a training session regimen [13], interhemispheric asymmetry of the brain [12], psychophysiological characteristics [14], 
an initial state of the autonomic nervous system (ANS) [17], and a biological type of athletes [15].

Examining the autonomic support of muscular activity in athletes enables an assessment of the ANS impact on achieving a high-level of sports performance at different ages, an identification of interaction patterns between the ANS divisions in the process of short-term and longterm adaptation to muscular load, identifying the features of the cardiovascular system autonomic regulation in athletes training different physical performance [9].

There are specific features of autonomic support in athletes with different modes of the training session, aerobic or speed-strength exercises, indicating a presence of specific "autonomic portraits" for certain sports. This characteristic should be taken into account when managing the training session and evaluating results in athletes, emphasizing not only the initial parameters, but also the autonomic response pattern, which determines the value of physiological activity in respect of proposed load [13].

However, there is an opposing opinion that the process of adaptation to muscular activity is determined not by sports specialization, but rather links to particular type of autonomic regulation [8].

A violation of autonomic regulation is also one of the causes of cardiovascular system pathology and sudden cardiac death in athletes [9] presenting an important challenge to examine changes in the autonomic regulation of the cardiovascular system and the energy supply of muscular activity in the process of adaptation to exercise in endurance-, strength-, and speed- trained athletes as well as determining the urgency of this issue.

\section{Aim}

To examine HRV changes in athletes depending on the training session mode.

\section{Material and methods}

After signing an informed consent, 104 athletes (84 men and 20 women) were enrolled in the study: 63 - endurance-trained athletes, 31 - strength-trained and 10 speed-trained athletes. The mean age of the athletes was $21.75 \pm 3.32$ years. Among them, there were Masters of Sports of International Class (MSIC) - 2 athletes, Masters of Sports (MS) - 25, Candidates Master of Sports (CMS) 48, First-Class athletes -29.

The study was performed on the device "Cardio+" (NPP "Metekol", Nizhyn). Mathematical methods of HRV analysis were used to analyze the autonomic regulation of the cardiac activity. The following parameters were evaluated: heart rate $(\mathrm{HR})$, mean cardiocycle duration (mean, ms), mode (Mo, $\mathrm{ms}$ ), amplitude mode (Amo,\%), variational range (X, s) and its analogue - triangular interpolation of NN intervals (TINN), triangular index (HRV triangular index), standard deviation of all 5-min average NN intervals (SDANN, ms), standard deviation of NN interval (SDNN, ms), square root of mean of the sum of squares of successive NN interval differences (RMSSD, ms), the number of successive NN interval differing by $>50$ ms divided by the total number of successive NN intervals (pNN50, mc), the coefficient of variation CVr, $\%$ - SDNN normalized to the average rhythm value, the coefficients of asymmetry (As) and kurtosis of the distribution (E). A number of derived indicators were calculated: autonomic equilibrium index $(A E I=A m o / X, \% / s)$, autonomic rhythm index (ARI, $\left.1 / \mathrm{s}^{2}\right)$, regulatory process stability index (RPSI, $\% / s$ ), stress index (SI, r. u.). Analysis and evaluation of HR frequency components was performed by assessing the spectral indicators of autocorrelation functions: total power spectrum (TP, $\mathrm{ms}^{2}$ ), very low frequency power (VLF, $\left.\mathrm{ms}^{2}\right)$, low $\left(\mathrm{LF}, \mathrm{ms}^{2}\right)$ and high $\left(\mathrm{HF}, \mathrm{ms}^{2}\right)$ frequency power, LF and $\mathrm{HF}$ in normalized units (LFn, \%, HFn, \%), the ratio of LF/HF (r. u.).

Statistical processing of the study results was performed using the software package Statistica for Windows 13 (StatSoft Inc., № JPZ804I382130ARCN10-J). The Shapiro-Wilk test was used to determine the normality of quantitative indicators distribution. Quantitative indicators were presented in the form of arithmetic mean and standard deviation, as well as medians and indicators of the $25^{\text {th }}$ and $75^{\text {th }}$ percentiles based on the normality of the data distribution. Comparison of quantitative indicators in independent groups was determined by the method of parametric statistics using the two-sample Student's t-test with a two-sided test index for a statistical significance value and by the method of nonparametric statistics using the Mann-Whitney U-test. The differences were considered statistically significant at a level of $P<0.05$.

\section{Results}

Comparison of HRV between the endurance- and strengthtrained athletes indicated a predominance of $\mathrm{HR}$ by $11.4 \%(61.03 \pm 10.19$ vs. $68.00 \pm 7.72$ bpm, $P=0.004)$ and a shorter mean duration of RR interval by $11.7 \%$ $(1002.45 \pm 168.59$ vs. $885.22 \pm 98.98 \mathrm{~ms}, \mathrm{P}=0.002)$ in the strength athletes (Table 1).

Apart from that, the endurance athletes showed significantly higher indicators of cardiac interval duration that was more frequently found in the given dynamic series (Mo) (954 $(860 ; 1103)$ vs. $868(798 ; 954) \mathrm{ms})$ by $9.0 \%(P=0.004)$ when compared with the strength-trained athletes.

The endurance-trained athlete also tended to prevail in relation to RMSSD, $P=0.066 ;$ SDNN, $P=0.093$, and SDANN, $P=0.063$, over these indicators in the strength athletes.

Thus, the endurance athletes differed by higher parasympathetic tone of the ANS from the strength athletes, as evidenced by a significantly lower HR by $11.4 \%$, prolonged RR interval by $11.7 \%$ and larger Mo value by $9.0 \%$.

Analysis of HRV between the endurance and speed athletes (Table 2) revealed significantly lower values of SDNN by $7.6 \%(P=0.048)$, RMSSD by $35.5 \%$ $(P=0.029)$, SDANN by $26.4 \%$, and larger Mo value by $4.1 \%(P=0.016)$ in the former.

There was no statistically significant difference between other HRV indicators in the endurance and speed athletes.

So, the endurance and speed athletes did not differ in all the frequency domain parameters and most of the time domain parameters of HRV, except for SDNN, RMSSD, SDANN and Mo.

Comparison of HRV parameters between the strength and speed athletes (Table 3) showed, that the strength athletes were more likely to have a significantly higher $\mathrm{HR}$ by $8.8 \%(P=0.042),(68.00 \pm 7.72$ vs. $62.00 \pm 7.14$ bpm $)$. 
Table 1. Parameters of heart rate variability in the endurance and strength athletes, $\mathrm{M} \pm \mathrm{SD}, \mathrm{Me}(\mathrm{Q} 25 ; \mathrm{Q} 75)$

\begin{tabular}{|c|c|c|c|c|}
\hline \multirow{2}{*}{$\begin{array}{l}\text { Parameter, } \\
\text { units of measure }\end{array}$} & \multicolumn{2}{|l|}{ Performance } & \multirow[t]{2}{*}{ P-level } & \multirow[t]{2}{*}{$\Delta \%$} \\
\hline & $\begin{array}{l}\text { Endurance } \\
(\mathrm{n}=60)\end{array}$ & $\begin{array}{l}\text { Strength } \\
(\mathrm{n}=31)\end{array}$ & & \\
\hline $\mathrm{HR}, \mathrm{bpm}$ & $61.03 \pm 10.19$ & $68.00 \pm 7.72$ & 0.004 & $-11.4 \%$ \\
\hline Mean, ms & $1002.45 \pm 168.59$ & $885.22 \pm 98.98$ & 0.002 & $+11.7 \%$ \\
\hline SDNN, ms & $79(54 ; 105)$ & $71(56 ; 81)$ & 0.093 & \\
\hline RMSSD, ms & $76(43 ; 113)$ & $61(44 ; 70)$ & 0.066 & \\
\hline SDANN, ms & $53(29 ; 71)$ & $39(32 ; 55)$ & 0.063 & \\
\hline pNN50, ms & $51(25 ; 65)$ & $39(15 ; 51)$ & 0.168 & \\
\hline CVr, \% & $7,8(6.0 ; 10.3)$ & $8.0(5.9 ; 9.7)$ & 0.639 & \\
\hline As & $0.04(-0.55 ; 0.36)$ & $0.10(-0.36 ; 0.49)$ & 0.927 & \\
\hline$E$ & $0.29(-0.26 ; 1.42)$ & $0.34(-0.29 ; 0.69)$ & 0.120 & \\
\hline $\mathrm{TP}, \mathrm{ms}^{2}$ & 1795 (1337; 2872) & $1728(1319 ; 2299)$ & 0.952 & \\
\hline VLF, $\mathrm{ms}^{2}$ & $774(410 ; 2037)$ & $998(472 ; 1696)$ & 0.335 & \\
\hline $\mathrm{LF}, \mathrm{ms}^{2}$ & $337(245 ; 443)$ & $336(252 ; 577)$ & 0.911 & \\
\hline LFn, \% & $56(35 ; 64)$ & $57(46 ; 70)$ & 0.349 & \\
\hline $\mathrm{HF}, \mathrm{ms}^{2}$ & $304(212 ; 443)$ & $273(216 ; 362)$ & 0.108 & \\
\hline $\mathrm{HFn}, \%$ & $44(36 ; 64)$ & $43(29 ; 53)$ & 0.349 & \\
\hline LF/HF & $1.30(0.56 ; 1.79)$ & $1.19(0.84 ; 2.06)$ & 0.828 & \\
\hline Mode, ms & $954(860 ; 1103)$ & $868(798 ; 954)$ & 0.004 & $+9.0 \%$ \\
\hline AMo, $\%$ & $6.80(5.25 ; 10.20)$ & $6.10(5.60 ; 7.90)$ & 0.083 & \\
\hline $\mathrm{X}, \mathrm{ms}$ & $461(308 ; 588)$ & $464(330 ; 497)$ & 0.647 & \\
\hline HRV Triangular Index & $15(9 ; 19)$ & $16(12 ; 17)$ & 0.339 & \\
\hline TINN, ms & $30(19 ; 38)$ & $32(25 ; 35)$ & 0.308 & \\
\hline $\mathrm{AEI}, \% / \mathrm{s}$ & $66(45 ; 127)$ & $66(46 ; 99)$ & 0.376 & \\
\hline ARI, 1/s2 & $2.27(1.60 ; 3.59)$ & $2.53(2.26 ; 3.46)$ & 0.777 & \\
\hline RPSI, \%/s & $31(23 ; 50)$ & $35(28 ; 42)$ & 0.810 & \\
\hline $\mathrm{SI}, \% / \mathrm{s} 2$ & $33(20 ; 69)$ & $44(26 ; 55)$ & 0.615 & \\
\hline
\end{tabular}

Table 2. Parameters of heart rate variability in the endurance and speed athletes, $\mathrm{M} \pm \mathrm{SD}, \mathrm{Me}(\mathrm{Q} 25 ; \mathrm{Q75})$

\begin{tabular}{|c|c|c|c|c|}
\hline \multirow{2}{*}{$\begin{array}{l}\text { Parameter, } \\
\text { units of measure }\end{array}$} & \multicolumn{2}{|l|}{ Performance } & \multirow[t]{2}{*}{ P-level } & \multirow[t]{2}{*}{$\Delta \%$} \\
\hline & $\begin{array}{l}\text { Endurance } \\
(n=60)\end{array}$ & $\begin{array}{l}\text { Speed } \\
(n=10)\end{array}$ & & \\
\hline $\mathrm{HR}, \mathrm{bpm}$ & $61.03 \pm 10.19$ & $62.00 \pm 7.14$ & 0.682 & \\
\hline Mean, ms & $1002.45 \pm 168.59$ & $969.56 \pm 112.28$ & 0.586 & \\
\hline SDNN, ms & $79(54 ; 105)$ & $85(58 ; 109)$ & 0.048 & $-7.6 \%$ \\
\hline RMSSD, ms & $76(43 ; 113)$ & $103(46 ; 120)$ & 0.029 & $-35.5 \%$ \\
\hline SDANN, ms & $53(29 ; 71)$ & $67(33 ; 76)$ & 0.027 & $-26.4 \%$ \\
\hline pNN50, ms & $51(25 ; 65)$ & $61(22 ; 67)$ & 0.260 & \\
\hline CVr, \% & $7.8(6.0 ; 10.3)$ & $9.2(6.4 ; 11.7)$ & 0.070 & \\
\hline As & $0.04(-0.55 ; 0.36)$ & $0.50(-0.40 ; 0.76)$ & 0.270 & \\
\hline$E$ & $0.29(-0.26 ; 1.42)$ & $0.52(0.28 ; 2.10)$ & 0.238 & \\
\hline $\mathrm{TP}, \mathrm{ms}^{2}$ & $1795(1337 ; 2872)$ & $1112(886 ; 2042)$ & 0.531 & \\
\hline $\mathrm{VLF}, \mathrm{ms}^{2}$ & $774(410 ; 2037)$ & $732(357 ; 1455)$ & 0.558 & \\
\hline $\mathrm{LF}, \mathrm{ms}^{2}$ & $337(245 ; 443)$ & $258(176 ; 368)$ & 0.570 & \\
\hline LFn, \% & $56(35 ; 64)$ & $46(27 ; 64)$ & 0.479 & \\
\hline $\mathrm{HF}, \mathrm{ms}^{2}$ & $304(212 ; 443)$ & $311(204 ; 458)$ & 0.233 & \\
\hline HFn, \% & $44(36 ; 64)$ & $54(35 ; 72)$ & 0.479 & \\
\hline $\mathrm{LF} / \mathrm{HF}$ & $1.30(0.56 ; 1.79)$ & $0.86(0.38 ; 1.80)$ & 0.926 & \\
\hline Mode, ms & $954(860 ; 1103)$ & $915(892 ; 1032)$ & 0.016 & $+4.1 \%$ \\
\hline AMo, $\%$ & $6.80(5.25 ; 10.20)$ & $6.10(4.20 ; 8.20$ & 0.134 & \\
\hline $\mathrm{X}, \mathrm{ms}$ & $461(308 ; 588)$ & $544(362 ; 706)$ & 0.061 & \\
\hline HRV Triangular Index & $15(9 ; 19)$ & $16(12 ; 23)$ & 0.253 & \\
\hline TINN, ms & $30(19 ; 38)$ & $33(24 ; 47)$ & 0.246 & \\
\hline $\mathrm{AEI}, \% / \mathrm{s}$ & $66(45 ; 127)$ & $42(26 ; 108)$ & 0.316 & \\
\hline ARI, 1/s2 & $2.27(1.60 ; 3.59)$ & $2.00(1.53 ; 2.76)$ & 0.481 & \\
\hline RPSI, \%/s & $31(23 ; 50)$ & $29(20 ; 39)$ & 0.422 & \\
\hline $\mathrm{SI}, \% / \mathrm{s} 2$ & $33(20 ; 69)$ & $25(14 ; 54)$ & 0.460 & \\
\hline
\end{tabular}

Compared to the speed athletes, the strength athletes had a significantly shortened RR interval (885.22 \pm 98.98 vs. $969.56 \pm 112.28 \mathrm{~ms})$ by $9.5 \%(P=0.046)$, lower values of SDNN by $9.5 \%(P=0.017)$, RMSSD by $68.9 \%$ $(P=0.012)$, SDDNN by $71.8 \%(P=0.015), C V r, \%$ by $15.0 \%(P=0.045)$, Mo by $5.4 \%(P=0.029)$, which pointed to sympathetic arm of the ANS overactivity in the strength athletes.

Thus, the speed-trained athletes and endurance-trained athletes differed from the strength-trained athletes by a higher parasympathetic tone as evidenced by a significantly lower HR by $8.8 \%(P=0.042)$, prolonged RR interval by $9.5 \%(P=0.046)$, higher values of SDNN by $9.5 \%$ $(P=0.017)$, RMSSD by $68.9 \%(P=0.012)$, SDDNN by $71.8 \%(P=0.015), C V r, \%$ by $15.0 \%(P=0.045), M o$ by $5.4 \%(P=0.029)$.

\section{Discussion}

Physiological parameters of autonomic cardiac regulation are objective criteria for assessing the functional state, adaptive and reserve capabilities, and fitness level in athletes [11].

The state of the organism can be described by three parameters: the level of a system functioning, the functional reserve, the degree of tension in regulatory mechanisms. Mathematically, the level of functioning in the organism, or the level of adaptation as a system, is determined by the Mo value. Mo is the value that appears most often in a set of 100-200 cardiac intervals studied. It characterizes the activity of the endocrine regulatory "channel". Amo reflects the sympathetic activity, and the cardiac intervals variability - the parasympathetic arm of the ANS activity. The resting HR is closely related to the Mo - the higher the Mo value, the lower is the resting HR. With increasing in training status from stage to stage, the Mo value increases and the resting HR decreases [2].

In our study, the endurance and speed athletes had significantly higher Mo values than the strength athletes. The data obtained indicated suppression of sympathetic activity of the ANS, decreased activity of the subcortical centers, confirming the high efficiency of autonomous regulation and the absence of centralization function control in the endurance-trained athletes and suggesting a high level of physical training in these athletes.

According to F. A. lordanskaya, systematic training mediates reconstruction of the $\mathrm{HR}$ regulatory mechanisms, improving the quality of vascular tone regulation, increasing the efficiency and effectiveness of the system at rest and during exercise [5].

Parameters of HRV also reflect the reserves of the cardiovascular system adaptive reorganization. HRV allows determining the state of autonomic homeostasis based on the degree of predominant activity of the sympathetic arm of the ANS and assessing the tension of regulatory systems by the activity level of the subcortical nerve centers. Measurement of the parameters can be performed both at the initial state of rest and during exercise or recovery period. Welltrained athletes demonstrated increased vagus nerve tone and reduced activity of the subcortical centers at rest, which points to a high efficiency of autonomous regulation and the absence of centralization function control. The ampli- 
tude of LF HR oscillation increased while the amplitude of respiratory oscillation reduced as an athlete's training status decreased. This is indicative of the subcortical nerve centers activation, strengthened centralization function control and increased tension of the regulatory mechanisms. The amplitude of HF HR oscillation increased and the amplitude of LF component decreased when the tension of adaptive processes decreased [2].

The literature data show the profiles of autonomic HR support in athletes depending on a biological type (sprinter-stayer) and sports qualification as well as on the mode of the training session and athletic discipline.

Kudrya O. M. reported improvements in the training status accompanied by elevated cholinergic effects on HR and changes in bio-energetics (increased oxidative and anaerobic-glycolytic capacity of the body) in representatives of cyclic (short-track) and team sports (handball) during the annual cycle. A decrease in performance was associated with increased centralization of HR control at rest and decreased functional activity of the sympathetic arm of the ANS when performing functional tests [9].

As shown by F. A. lordanskaya, the parasympathetic type of the cardiovascular system autonomic regulation is prevailing in the process of long-term adaptation in elite rowers that follows from bradycardia at rest in the supine position (HR 60 to $40 \mathrm{bpm}$ ) and autonomic index more than 11 units, or normotony (autonomic index \pm 10 units) [6].

The spectral analysis of the slow-wave component revealed differences in the mechanisms of cardiovascular system regulation in swimmers during the preparatory and competitive periods. The sprinter swimmers exhibited the central mechanisms predominance, namely suprasegmental level (VLF) and sympathetic arm of the ANS (LF), while the stayer swimmers appeared to have predominantly $\mathrm{HF}$ component in the cardiac rhythm regulation $[4,15]$.

In order to clarify the differences between the autonomic support of heart rhythm in endurance-trained and speedstrength-trained athletes, O. M. Kudrya examined 69 elite athletes at the pre-competition period. The first group included 30 athletes, who trained mainly aerobic endurance performance (track and field, cycling and swimming). The second group consisted of 39 individuals focused on the speed and power component (ball hockey, boxing, tennis). There were no significant differences in the percentage of spectrum components and physical performance according to the $\mathrm{PWC}_{170}$ test results between the groups at baseline. However, the absolute values of HF power were significantly higher in endurance-trained athletes. Noticeable differences between the two groups were found after exposure to submaximal load $\mathrm{PWC}_{170}$. The author underlined the "economic" type of response, typical for the 1st group athletes with a smaller increment in HR after exercise, almost unchanged values of $\mathrm{SI}$, total power spectrum and its constituent components, except for a significant reduction in VLF values (i.e. a reduction in the share of the central control loop influence). This type of autonomic response was accompanied by a rapid recovery of $\mathrm{HR}$ after exercise. A type of response to the submaximal load can be characterized as more demanding in speed and endurance athletes in terms of the energy metabolism, when the functional system must be put into functioning immediately. Athletes of this group showed a noticeable increase in $\mathrm{HR}$ and $\mathrm{SI}$, significantly lower rate of pulse recovery
Table 3. Parameters of heart rate variability in the strength and speed athletes, $M \pm S D, M e(Q 25 ; Q 75)$

\begin{tabular}{|c|c|c|c|c|}
\hline \multirow{2}{*}{$\begin{array}{l}\text { Parameter, } \\
\text { units of measure }\end{array}$} & \multicolumn{2}{|l|}{ Performance } & \multirow[t]{2}{*}{ P-level } & \multirow[t]{2}{*}{$\Delta \%$} \\
\hline & $\begin{array}{l}\text { Strength } \\
(\mathrm{n}=31)\end{array}$ & $\begin{array}{l}\text { Speed } \\
(\mathrm{n}=10)\end{array}$ & & \\
\hline $\mathrm{HR}$, bpm & $68.00 \pm 7.72$ & $62.00 \pm 7.14$ & 0.042 & $+8.8 \%$ \\
\hline Mean, ms & $885.22 \pm 98.98$ & $969.56 \pm 112.28$ & 0.046 & $-9.5 \%$ \\
\hline SDNN, ms & $71(56 ; 81)$ & $85(58 ; 109)$ & 0.017 & $-19.7 \%$ \\
\hline RMSSD, ms & $61(44 ; 70)$ & $103(46 ; 120)$ & 0.012 & $-68.9 \%$ \\
\hline SDANN, ms & $39(32 ; 55)$ & $67(33 ; 76)$ & 0.015 & $-71.8 \%$ \\
\hline pNN50, ms & $39(15 ; 51)$ & $61(22 ; 67)$ & 0.121 & \\
\hline $\mathrm{CVr}, \%$ & $8.0(5.9 ; 9.7)$ & $9.2(6.4 ; 11.7)$ & 0.045 & $-15.0 \%$ \\
\hline As & $0.10(-0.36 ; 0.49)$ & $0.50(-0.40 ; 0.76)$ & 0.241 & \\
\hline E & $0.34(-0.29 ; 0.69)$ & $0.52(0.28 ; 2.10)$ & 0.937 & \\
\hline $\mathrm{TP}, \mathrm{ms}^{2}$ & $1728(1319 ; 2299)$ & $1112(886 ; 2042)$ & 0.304 & \\
\hline $\mathrm{VLF}, \mathrm{ms}^{2}$ & $998(472 ; 1696)$ & $732(357 ;$ 1455) & 0.478 & \\
\hline$L F, \mathrm{~ms}^{2}$ & $336(252 ; 577)$ & $258(176 ; 368)$ & 0.249 & \\
\hline LFn, \% & $57(46 ; 70)$ & $46(27 ; 64)$ & 0.233 & \\
\hline $\mathrm{HF}, \mathrm{ms}^{2}$ & $273(216 ; 362)$ & $311(204 ; 458)$ & 0.558 & \\
\hline HFn, \% & $43(29 ; 53)$ & $54(35 ; 72)$ & 0.233 & \\
\hline LF/HF & $1.19(0.84 ; 2.06)$ & $0.86(0.38 ; 1.80)$ & 0.818 & \\
\hline Mode, ms & $868(798 ; 954)$ & $915(892 ; 1032)$ & 0.029 & $-5.4 \%$ \\
\hline AMo, $\%$ & $6.10(5.60 ; 7.90)$ & $6.10(4.20 ; 8.20$ & 0.896 & \\
\hline $\mathrm{X}, \mathrm{ms}$ & $464(330 ; 497)$ & $544(362 ; 706)$ & 0.069 & \\
\hline HRV Triangular Index & $16(12 ; 17)$ & $16(12 ; 23)$ & 0.348 & \\
\hline TINN, ms & $32(25 ; 35)$ & $33(24 ; 47)$ & 0.379 & \\
\hline AEI, \%/s & $66(46 ; 99)$ & $42(26 ; 108)$ & 0.250 & \\
\hline ARI, 1/s2 & $2.53(2.26 ; 3.46)$ & $2.00(1.53 ; 2.76)$ & 0.114 & \\
\hline RPSI, \%/s & $35(28 ; 42)$ & $29(20 ; 39)$ & 0.164 & \\
\hline $\mathrm{SI}, \% / \mathrm{s} 2$ & $44(26 ; 55)$ & $25(14 ; 54)$ & 0.213 & \\
\hline
\end{tabular}

after the test, there was a decrease in autonomic reactivity in all the frequency spectrums, and structural analysis demonstrated a clear increase in control centralization with increasing vector VLF \% and regressive vector $\mathrm{HF} \%$ after muscle loading. In this case, the cost of physical activity was higher in the 2 nd group of athletes, than that in the aerobic endurance athletes [9].

Mykhaliuk Ye. L. and co-authors showed a significant difference in autonomic support depending on the sport class of swimmers. It has been proved, that the MS-MSIC swimmers, unlike the CMS-First-Class swimmers, were significantly older, had a greater experience in swimming, and body length and weight as well as relative physical performance, lower HR; they tended to have predominantly hypokinetic type of blood circulation, and there were mainly athletes with vagotonia among them [18].

Changes in HRV in sprinters, obtained by M. V. Didenko and co-authors, testify to the parasympathetic arm of the ANS prevalence associated with hypokinetic type of blood circulation and a greater physical performance. The researchers linked these changes to the specifics of physical activity in short-distance runners - the work of maximum intensity (80-90\% from a maximum) and minimum duration (5-20 seconds) provided by the creatine phosphate system. The training session performed was accompanied by increased $\mathrm{HR}$ and placed heavy demands on the cardiovascular system state in the sprinters. Such physical activity is often the cause of an athlete's adaptive potential depletion and maladaptation affecting the autonomic support of heart rhythm, central hemodynamics, as well as physical performance [3]. 
We obtained unidirectional shifts in autonomic balance towards increased parasympathetic effects in the endurance- and speed-trained athletes compared with the strength-trained athletes, as evidenced by the predominance of RMSSD, SDANN, Mo, RR interval duration and significantly lower resting HR that is consistent with the previous literature.

In the opinion of V. V. Erlikh, competition load in weightlifting does not cause maximum increases in HR and stroke volume. Baseline values of resting HR exceed these indicators in cyclic athletes. Weightlifters do not have bradycardia, but on the contrary, show hypertensive reactions of blood pressure, HR, especially in heavyweight athletes [16].

According to O. V. Calabin, HRV parameters (SDNN, rMSSD, pNN50, TP, HF) in powerlifters were significantly lower, but LF/HF were higher than those in healthy untrained people, indicating increased sympathetic effects and centralized HR control. Differential characteristic of HR in elite athletes were: reduced HRV (low values of rMSSD, pNN50) with a predominance of sympathetic activity in the autonomic balance (high values of $\mathrm{Amo}, \mathrm{SI}$ ), as well as a significant decrease in spectral power within all the frequency ranges as compared to competitive athletes [7].

The results of our study have demonstrated no significant differences in spectral HRV parameters in the strength and endurance/speed athletes. Meanwhile, the strength athletes had the highest HR at rest and the lowest Mo value, which indicated the predominant activity of the sympathetic arm of the ANS.

Lingard's phenomenon should also be taken into account when assessing the HRV in the strength athletes autonomic support of static activity is characterized by delayed autonomic shifts with the maximum in the first minutes of the recovery period rather than in isometric exercise [1].

Today, there is convincing evidence about HRV parameters changes mediated by regular physical activity depending on height, age, sex, baseline state of the autonomic balance, psychophysiological status in athletes.

So, O. M. Kudrya has revealed the features of the cardiac activity autonomic support depending on anthropometric profiles in team-sport athletes aged 15-16 years. Regulatory mechanisms tension at rest has been found in tall young males as well as a decrease in the sympathetic arm of the ANS functioning during an active orthostatic test in athletes of both sexes. The urgent adaptation of the cardiovascular system to external factors in tall athletes, in the author's opinion, was associated with suprasegmental effects of the ANS and sympathetic hyperactivity enabling ineffective adaptation [10].

In a study [14] of the relationship between the autonomic regulation type and psychophysiological characteristics, a total of 77 male wrestling athletes aged 18-21 years were enrolled. The authors have found the following relationships: 1) athletes-vagotonics were characterized mainly by choleric temperament, moderate extraversion, unstable multidirectional emotional resilience, medium-level of state and trait anxiety; 2) eutonic athletes were characterized by sanguine temperament, moderate extraversion, medium emotional resilience and mood swings in equal measure (50\%/50\%), medium-level of state and trait anxiety; 3) sympathicotonic athletes were characterized by a strong type of nervous system (67\% choleric and $33 \%$ sanguine), moderate extroversion, high-level of state and trait anxiety.

The researchers hypothesized, that in the eutonic group with the lowest number of correlations between indicators, the functional system was more stable and less vulnerable to environmental influences. In the groups with a large number of correlations (sympathicotonics, vagotonics), the functional system was in the process of stability adjustment, the relationships were more likely to be affected by environmental factors and plastic. Thus, the greater number of correlations reflected an insufficient maturity of functional systems attuning of new links to support the activity [14].

lordanskaya F. A. and co-authors have found an association between the level of orthostatic autonomic stability and both a higher stature and in-game role in volleyball players as well as between the effect of speed-strength load on blood pressure and ECG indicators and both age and sex parameters in rowers. An assessment of the response to orthostasis being compared to the criteria for elite athletes allowed researchers to diagnose reduced indicators and low orthostatic stability in individual athletes, which pointed to symptoms of the cardiovascular system maladaptation. The presence of maladaptation symptoms related to an athletic performance has been confirmed when compared with results of exercise tests. The authors concluded, that reduced and low levels of the ANS response to orthostasis (tachycardia $\Delta \mathrm{HR}+36 \mathrm{bpm}$ and more, symptoms of myocardial repolarization violation, signs of the left ventricle systolic overload, prolonged QT, hypertension, extrasystole) should be considered as early signs of the cardiovascular system overload, which necessitate urgent measures to correct training load and rehabilitation plan for athletes [5].

Age peculiarities of HRV were demonstrated in a study [9]. The author has proved that the baseline activity of the ANS arms determines the mechanisms of long-term adaptation to muscular load. A predominance of the sympathetic arm of the ANS baseline activity ensures a high level of performance in submaximal mode in child and adolescent athletes while in adult athletes, the baseline activity of the sympathetic arm seems to be limiting factor when performing physical exercise. On the contrary, the baseline predominance of the parasympathetic arm of the ANS activity reduces the level of physical performance in the submaximal mode in young athletes, but vagotonics develop increased body adaptation and exercise capacity with increasing age and sports experience [9].

It has been proved that the character of changes in the autonomic balance depends not only on the mode of training session, but also on the baseline autonomic tone. According to S. V. Yakhontov, asanas had the most beneficial effects in sympathicotonics and hypersympathicotonics, increasing parasympathetic activity by $85 \%$ while reducing sympathetic activity by $28 \%$. Besides, there was a decrease in SI by $41 \%$ and HR by $13 \%$. A less noticeable effect was observed when using dynamic exercises. In vagotonics, the most apparent effect was caused by endurance exercises with a $67.5 \%$ increase in SI. Artistic gymnastics caused a similar, but less persuasive effect [17].

Nowadays, one of the factors for reaching the maximum sports performance is the brain functional asymmetry in athletes, as a basis of individual motor activity is the lateral phenotype which regulates the age and gender specifics of 
its organization and management. It has been shown, that sporting success in specific sports, as well as the optimal adaptation to maximum permissible (extreme) physical and mental loads in elite sports, is determined by the lateral phenotype. M. V. Maler has revealed an optimal autonomic regulation of the cardiovascular system in young men with the left lateral phenotype, as well as in athletes with predominantly left lateral phenotypes and right sensory prevalence. In female athletes, the optimal autonomic regulation in conditions of relative rest was observed in the group of girls with a predominantly right-handed phenotype with a left leading ear. It has been demonstrated, that in the aerobic energy metabolism mode, athletes of both sexes with different lateral phenotypes were able to demonstrate the same physical performance. In persons with lateral phenotypes of the cardiovascular system activity, the author has found differences in energy supply of the muscular activity in anaerobic conditions. So, female athletes of mainly right lateral phenotype with the left leading ear reached a higher physical capacity at loading via the most economic way in the lack of oxygen conditions. Young athletes with different lateral phenotypes did not show differences in physical performance in the aerobic energy supply [12].

HRV and central hemodynamics in elite athletes with different activity of autonomic regulation were studied [8]. Based on the values of SI, VLF power and the classification of N. I. Shlyk (1992), the athletes were divided into four groups of autonomic regulation. The study reported that athletes with different activity of the body regulatory systems had a different correlation between HRV parameters and central hemodynamic parameters: in group I athletes, HRV parameters correlated with those hemodynamic parameters which mainly reflect the heart hemodynamic performance (HR, CO, SO, Cl, SI, COI, SOI, TPVR), and in group III athletes - with indicators, which reflect heart pump function (HR, CO, SO, Cl, SI, COI, SOI, TPVR), and hemodynamics (systolic blood pressure, diastolic blood pressure, average blood pressure) indicating differences in the adaptive mechanisms between group I and group III athletes, as the author noted.

Different variants of HRV and central hemodynamic response to the Martinet's test in group I and group III athletes were also identified, reflecting the different reserve capabilities of the circulatory system. Athletes with hyperactivity of the parasympathetic arm of the ANS and central mechanisms of regulation (group III) during Martinet's test exhibited an increase in adrenergic effects on HR (autonomic-central response) accompanied by an increase in systolic blood pressure, diastolic blood pressure and mean blood pressure. Athletes with hyperactivity of the sympathetic arm of the ANS and central regulatory mechanisms (group I) during the test showed an increase in adrenergic effects on HR amid dysregulatory manifestations of both the sympathetic and parasympathetic arms of the ANS (central variant of the reaction), that was evident as increased $H R$, cardiac output, cardiac index). All this indicated a more pronounced reserve capacity of the circulatory system in group III athletes in comparison with group I athletes. In volleyball players, biathletes, gymnasts, football players and swimmers, who belonged to group III of autonomic regulation, the values of HRV and hemodynamics were similar. Therefore, it was concluded, that the adaptive pro- cess to muscular activity is determined by the belonging to a particular group of autonomic regulation rather than sports specialization [8].

Our study has revealed the presence of autonomic supply specifics in the athletes with different mode of the training session.

\section{Conclusions}

1. The endurance and speed athletes did not differ from each other in all spectral and the vast majority of time domain HRV parameters, except for SDNN, RMSSD, SDANN and Mo.

2. The strength athletes differed from the endurance athletes by higher tone of the sympathetic arm of the ANS, as evidenced by significantly $11.4 \%$ higher heart rate, $11.7 \%$ shorter RR interval duration and $9.0 \%$ lower Mo value.

3. The speed and endurance athletes differed from the strength athletes by higher parasympathetic tone as evidenced by significantly $8.8 \%(P=0.042)$ lower heart rate, $9.5 \%(P=0.046)$ higher $R-R$ interval duration, values of SDNN by $9.5 \%(P=0.017)$, RMSSD by $68.9 \%$ $(P=0.012)$, SDANN by $71.8 \%(P=0.015), C V r, \%$ by $15.0 \%(P=0.045)$, Mo by $5.4 \%(P=0.029)$.

Conflict of interest: authors have no conflict of interest to declare. Конфмікт інтересів: відсутній.

НаАійшла Ао реАакції / Received: 03.09.2020

Після Аоопрацювання / Revised: 30.09.2020

Прийнято Ао Аруку / Accepted: 07.10.2020

Information about authors:

Kanyhina S. M., MD, PhD, Associate Professor of the Department of Physical Rehabilitation, Sports Medicine, Physical

Education and Health, Zaporizhzhia State Medical University,

Ukraine.

ORCID ID: 0000-0002-8197-299X

Syvolap V. V., MD, PhD, DSc, Professor, Head of the Department of Propedeutics of Internal Medicine, Radiation Diagnostic and Radiation Therapy, Zaporizhzhia State Medical University, Ukraine. ORCID ID: 0000-0001-9865-4325

Potapenko M. S., MD, PhD, Assistant of the Department of Anesthesiology and Intensive Care, Zaporizhzhia State Medical University, Ukraine.

\section{Відомості про авторів:}

Канигіна С. М., канд. меА. наук, Аоцент каф. фізичної реабілітації, спортивної меАицини, фізичного виховання і зАоров'я, Запорізький Аержавний медичний університет, Україна.

Сиволап В. В., А-р меА. наук, професор, зав. каф. пропедевтики внутрішньої медицини, променевої діагностики та променевої терапії, Запорізький державний медичний університет, Україна. Потапенко М. С., канд. меА. наук, асистент каф. анестезіології та інтенсивної терапії, Запорізький державний медичний університет, Україна.

\section{Сведения об авторах:}

Каныгина С. Н., канА. меА. наук, Аоцент каф. физической реабилитации, спортивной медицины, физического воспитания и зАоровья, Запорожский государственный медицинский университет, Украина.

Сыволап В. В, А-р меА. наук, профессор, зав. каф. пропедевтики внутренней медицины, лучевой диагностики и лучевой терапии, Запорожский государственный медицинский университет, Украина. 
Потапенко М. С., канА. меА. наук, ассистент каф. анестезиологии и интенсивной терапии, Запорожский государственный медицинский университет, Украина.

\section{References}

[1] Aghajanyan, M. G., \& Pilosyan, L. G. (2018). Znachenie izometricheskikh napryazhenii v myshechnoi deyatel'nosti cheloveka [The Significance of Isometric Contraction in Human Muscular Performance]. Meditsinskaya nauka Armenii NAN RA, LVIII(4), 105-113. [in Russian]

[2] Bayevsky, R. M., \& Ivanov, G. G. (2001). Variabel'nost' serdechnogo ritma: teoreticheskie aspekty i vozmozhnosti klinicheskogo primeneniya [Cardiac Rhythm Variability: the Theoretical Aspects and the Opportunities of Clinical Application (Lecture)]. Ul'trazvukovaya i funktsional'naya diagnostika, (3), 108-127. [in Russian].

[3] Didenko, M. V., Mikhalyuk, E. L., \& Malakhova, S. N. (2014). Vegetativnoe obespechenie pokazatelei serdechno-sosudistoi sistemy i fizicheskoi rabotosposobnosti legkoatletok-sprinterov [Vegetative provision indicators of cardiovascular system and physical effi ciency of women athlet-sprinters]. Zaporozhye medical journal, (1), 16-19. https://doi. org/10.14739/2310-1210.2014.1.23647 [in Russian]

[4] Zhukova, A. A., Budko, L. A., \& Sevostyanov, P. A. (2014). Sravnitel'naya otsenka vegetativnoi regulyatsii serdechnogo ritma u plovtsov i gimnastov [The comparative assessment of vegetative regulation of heart rhythm in swimmers and gymnasts]. Problemy zdorov'ya i ekologii, (2), 100-104. [in Russian].

[5] Iordanskaya, F. A., \& Buchina, E. V. (2017). Ortostaticheskaya ustoichivost' v vegetativnom obespechenii rabotosposobnosti vysokokvalifitsirovannykh sportsmenov [Orthostastic stability in the vegetative maintenance of the working ability of elite athletes]. Vestnik sportivnoi nauki, (4), 26-34. [in Russian].

[6] Iordanskaya, F. A., Buchina, E. V. \& Tsepkova, N. K. (2016). Vozrastno-polovye osobennosti adaptatsii serdechno-sosudistoi i vegetativnoi nervnoi sistemy v obespechenii rabotosposobnosti grebtsov-akademistov [Age and sex characteristics of the cardiovascular and autonomic nervous system adaptation in providing of working ability in academics rowers]. Vestnik sportivnoi nauki, (3), 29-38. [in Russian]

[7] Kalabin, O. V., \& Spitsin, A. P. (2018). Osobennosti variabel'nosti serdechnogo ritma pauerlifterov pri vozdeistvii trenirovochnogo protsessa [Features of the heart rate variability of powerlifters under the influence of the training process]. Yakutskii meditsinskii zhurnal, (1), 30-32. https:// doi.org/10.25789/YMJ.2018.61.09 [in Russian].

[8] Krasnoperova, T. V. (2005). Variabel'nost' serdechnogo ritma i tsentral'naya gemodinamika u vysokokvalifitsirovannykh sportsmenov s raznoi aktivnost'yu vegetativnoi regulyatsii. (Dis... dokt. biol. nauk). [Heart rate variability and central hemodynamics in highly qualified athletes with different activity of autonomic regulation. Dr. biol. sci. diss.]. Kirov. [in Russian].

[9] Kudrya, O. N. (2012). Fiziologicheskie osobennosti vegetativnogo obespecheniya myshechnoi deyatel'nosti u sportsmenov. (Dis... dokt. biol. nauk). [Physiological features of autonomic support of muscle activity in athletes. Dr. biol. sci. diss.]. Omsk. [in Russian]

[10] Kudrya, O. N. (2016). Vegetativnoe obespechenie serdechnoi deyatel'nosti u sportsmenov s raznym antropometricheskim profilem [Vegetative support of cardiac activity in athletes with different anthropometric profile]. Bulletin of Siberian Medicine, 15(3), 63-69. https:// doi.org/10.20538/1682-0363-2016-3-63-69 [in Russian].

[11] Litvin, F. B., Brook, T. M., Osipova, N. V., Balabokhin, T. V., \& Lyubutina, K. D. (2016). Sostoyanie vegetativnoi regulyatsii serdechnogo ritma u futbolistov na etapakh godichnogo trenirovochnogo tsikla [Condition of vegetative regulation of the warm rhythm at football players at stages of the year training cycle]. The heart rhytm and the type of autonomic regulation in assessing the health of the population and functional training of athlete: Proceedings of the VI All Russia Symposium with international participation, dedicated to the memory of Academician Vasily Vasilievich Parin. (pp. 175-181). Udmurtskii universitet. [in Russian].

[12] Maler, M. V. (2009). Osobennosti deyatel'nosti serdechno-sosudisto sistemy vysokokvalifitsirovannykh sportsmenov s razlichnymi lateral'nymi fenotipami. (Dis... kand. biol. nauk). [Features of the activity of the cardiovascular system in highly qualified athletes with different lateral phenotypes. Dr. biol. sci. diss.]. Cheboksary. [in Russian].

[13] Markov, K. K., Ivanova, O. A., Sivokhov, V. L., \& Sivokhova, E. L. (2015). Osobennosti vegetativnoi reaktivnosti u sportsmenov s raznoi napravlennost'yu trenirovochnogo protsessa [Features of vegetative reactance at sportsmen with a different orientation of training process]. Fundamental'nye issledovaniya, (2-19), 4304-4308. http://www.fundamental-research.ru/ru/article/view?id=37948 [in Russian].

[14] Medvedev, D. S., Churganov, O. A., Schurov, A. G., \& Bondarev, S. A. (2016). Vzaimosvyazi vegetativnogo tonusa s psikhofiziologicheskoi kharakteristikoi sportsmenov kak osnova dlya funktsional'noi tipologizatsii (na primere sportsmenov, zanimayushchikhsya sportivnoi bor'boi) [The relationship of autonomic tone to psycho-physiological characteristics of athletes as a basis for a functional typology (example of athletes involved in wrestling)]. Sovremennye problemy nauki i obrazovaniya, (6), http://www.science-education.ru/ru/article/ view?id=25625 [in Russian]

[15] Sukach, E. S., Povchinik, D. A., \& Kozlovskaya, T. V. (2019). Osobennosti variabel'nosti serdechnogo ritma i tsentral'noi gemodinamiki u sportsmenov-plovtsov vo vremya trenirovochnogo protsessa [Features of heart rate variability and central hemodynamics in athletes-swimmers during the training process]. Specific and nonspecific mechanisms of adaptation under stress and exercises: abstracts of articles of the 3rd National scientific and practical Internet conference with international participation. (pp. 107-111). GomGMU. [in Russian].

[16] Erlikh, V. V., Isaev, A. P., \& Khomenko, R. V. (2011). Sostoyanie gomeostaza i fizicheskoi rabotosposobnosti yunykh tyazheloatletov $v$ protsesse podgotovki k sorevnovaniyam [State of homeostasis and physical performance of young weightlifters in preparation for competition]. Vestnik Yuzhno-Ural'skogo gosudarstvennogo universiteta. Seriya Obrazovanie, zdravookhranenie, fizicheckaya kyl'tura, (2), 26-33. [in Russian].

[17] Yakhontov, S. V., Kulemzin, A. V., Chufistova, O. N., \& Zarapov, D. V. (2015). Vegetativnaya ustoichivost' $v$ sporte [Vegetative sustainability in sport]. Vestnik Tomskogo gosudarstvennogo pedagogicheskogo universiteta, (3), 224-231. [in Russian].

[18] Mykhaliuk, Ye. L., Potapenko, M. S., Horokhovskyi, Ye. Yu., Hunina, L. M., \& Holovashchenko, R. V. (2020). Characteristics of autonomic maintenance of central hemodynamics and physical working capacity in highly qualified sprint swimmers. Zaporozhye medical journal, 22(2) 245-249. https://doi.org/10.14739/2310-1210.2020.2.200627 